\title{
The Effect of Reconstruction of the Critical Size Defect by Titanium Mesh in the Developing Rabbit Calvarium to Calvarium Development
}

\section{Gelişen Tavşan Kalvaryumunda Oluşturulan Kritik Boyutlu Defektin Titanyum Meş ile Rekonstrüksiyonun Kalvaryum Gelişimine Etkisi}

Mustafa Kursat Evrenos ${ }^{1}$, Mehmet Emin Mavili²,

${ }^{1}$ Celal Bayar University, Faculty of Medicine Department of Plastic Reconstructive and Aesthetic Surgery, Manisa ${ }^{2}$ Hacettepe University, Faculty of Medicine, Department of Plastic Reconstructive and Aesthetic Surgery, Ankara

Gelis Tarihi/Received: 28 June 2018 Kabul Tarihi/Accepted: 15 August 2018

\begin{abstract}
Öz
Amaç: Gelişen kalvaryum defekt rekonstrüksiyonu hala zorlu bir prosedürdür. Kullanılan materyaller sağlamlık ve koruma sağlamalı; hafif, kimyasal olarak inert, kanserojen olmayan, estetik sonucu arttırmak için kolay sekillenebilir olmalı, manyetik rezonans görüntülemeye izin vermek için demir içermemelidir ve osteokondüktif ve osteojenik olmalıdır. Ayrıca, alloplastik materyalin avantajı, donör alan morbiditesine yol açmaz ve sınırsız bir tedarik sağlar. Ideal bir implant hala tanımlanmamış olsa da, titanyum meş kabul edilebilir alternatiflerden biridir. Bu çalışmada, titanyum meş implantın gelişen kalvaryumdaki defektlerin rekonstrüksiyonunda kullanılabileceği ve implantın rijid veya semirijid fiksasyonu ile sekonder asimetri deformitesine yol açıp açmadığı değerlendirildi.

Gereçler ve Yöntem: 6 haftalık 24 Yeni Zelanda tavşanı dört eşit gruba ayrıldı. Birinci grup normal popülasyon grubuydu. İkinci, üçüncü ve dördüncü gruplarda her bir tavşanın pariyetal kemiği üzerinde 15 $\mathrm{mm}$ çaplı kritik boyutlu defekt oluşturuldu. İkinci grup kritik boyutlu defekt için sham grubu olarak belirlendi. Üçüncü grupta defektler $0.3 \mathrm{~mm}$ kalınlıkta titanyum meşin 4.0 polipropilen sütür ile semirijid olarak fikse edilmesiyle; 4. grupta ise aynı kalınlıkta titanyum meşin $4 \mathrm{~mm}$ çaplı titanyum vidalarla rijit fiksasyonuyla rekonstrükte edildi. Başlangıçta, tavşan kalvaryumu kraniyal bilgisayarlı tomografi (BT) ile tarandı ve üç boyutlu rekonstrüksiyonlar oluşturuldu. Deney, tavşanlar 18 haftalıkken sonlandırıldı. Tüm gruplarda her tavşan için sakrifikasyon ve kraniyal BT taraması yapıldı ve standart fotoğraflar alındı. Uzunluk ölçümleri referans noktalarından gerçekleştirildi ve gruplar arasında karşılaştırmalar yapıldı.

Bulgular: 6 haftalık üç boyutlu bilgisayarlı tomografi ölçümlerine göre, grupların dengeli dağıldığı değerlendirildi. 18 haftalık 3D BT ölçümlerine göre gruplar arasında istatistiksel fark saptanmadı. Ayrıca her grupta defekt tarafı ve karşı taraf ölçümlerinde istatistiksel olarak farklılık saptanmadı.

Sonuç: Titanyum meşin, büyüme gösteren kalvaryumda herhangi bir deformiteye neden olmadığını ve meş fiksasyon tekniğinin sonucu değiştirmediğini değerlendirdik. Dolayısıyla pediatrik kalvaryum defektlerinde, otojen kemik grefti ile rekonstrüksiyonun mümkün olmaması durumunda, titanyum meş ile rekonstrüksiyon kabul edilebilir bir seçenek olabilir.
\end{abstract}

Anahtar Kelimeler: kritik boyutlu defekt, gelişen kalvaryum, rijid fiksasyon, semirijid fiksasyon, titanyum meş.

\begin{abstract}
Aim: Defect reconstruction of growing calvarium is still challenging procedure. The materials should provide strength and protection, be lightweight, chemically inert, noncarcinogenic, malleable to enhance aesthetic outcome, nonferrous to allow utilization of magnetic resonance imaging, and osteoconductive and osteogenic. In addition, the advantages of alloplastic material avoid donor site morbidity and provide an unlimited supply. Although an ideal implant is not still defined, titanium mesh is one of the acceptable alternatives. In this study, we evaluated that if titanium mesh implant can be used for reconstruction of defects in growing calvarium and caused a secondary asymetry deformity with rigid or semirigid fixation of implant.

Materials and Methods: 6 week-old 24 New Zealand rabbits were used and divided into four equal groups. First group was normal population group. $15 \mathrm{~mm}$. diameter critical size defects were created on parietal bone of each rabbit in second, third and fourth groups. Second group was decided as sham group for critical size defect. Defects were reconstructed with $0.6 \mathrm{~mm}$. thickness titanium mesh and fixed with 4.0 polypropylene sutur in the third group as semirigid fixation and with $4 \mathrm{~mm}$. Iong titanium screws as rigid fixation in the fourth group. At the beginning, rabbit calvarias were scanned with cranial CT and $3 \mathrm{D}$ reconstructions were created. Experiment finished when rabbits were 18 weeks old. Sacrifisation and cranial CT scan performed and standart photographs were taken for each rabbit in all groups. The length measurements were performed from reference points and comparisons were made between groups. Results: According to 6 week 3D CT measurements, groups were well-balanced. According to 18 week 3D CT measurements there was no statistically difference between groups. Also measurements of defective side and opposite side in each group were not different.

Discussion: We evaluated that the titanium mesh did not cause any deformity in growing calvarium and fixation technique of the mesh did not change the result. So in defects of pediatric calvarium, if reconstruction with autogen bone graft is impossible, reconstruction with titanium mesh can be an acceptable choice.
\end{abstract}

Key words: critical size defect, growing calvarium, rigid fixation, semirigid fixation, titanium mesh.

Address correspondence to: Mustafa Kursat Evrenos, Celal Bayar University, Faculty of Medicine, Department of Plastic Reconstructive and Aesthetic Surgery, Manisa e-mail:mkevrenos@hotmail.com

Cite this article as: Evrenos MK, Mavili ME. The Effect of Reconstruction of the Critical Size Defect by Titanium Mesh in the Developing Rabbit Calvarium to Calvarium Development. Selcuk Med J 2018;34(4): 165-171

\section{Disclosure: None of the authors has a financial interest in any of the products,} devices, or drugs mentioned in this article. This study was supported by Hacettepe University Coordination Department of Scientific Research Projects with the project number of 010D09101008 in 2011.All authors have agreed to allow full access to the primary data and to allow the journal to review the data if requested. There is no conflict of interest between the authors. 


\section{INTRODUCTION}

The surgical repair of large defects of the growing calvarium is still a debating procedure for craniofacial surgeons. Autogenous bone grafts are the gold standard for calvarial defect reconstruction in children as a result of their capacity to become integrated with time and keep growing with the growth of the pediatric skeleton (1). However, the donor side morbidity and the limited size of available tissue limit its usage. In addition, bone grafts may undergo resorption and this may not be predictible, resulting a necessity for secondary reconstruction (2). The proporties of ideal material for calvarium reconstructions are; should be easy to contour, radiolucent, well tolerated in biological systems, osteoinductive and osteoconductive, also resist mechanical loading (3). Many alloplastic materials have been used for calvarial defect reconstruction, such as polymethylmethacrylate, polythene, polypropylene polyester, ceramic, and titanium plates and mesh. Several complications such as skin breakdown, implant exposure and extrusion, and infection can be seen after reconstruction with these materials. Titanium mesh is resistant to infection, ensures structural stability, is relatively inexpensive, but can be hard to shape when not preformed (4). It has been used successfully in adults (4-7) but there is limited data for growing calvarium or pediatric population and its complications such as secondary developmental asymetry (8-10). In this report, we evaluated if titanium mesh causes a secondary developmental asymetry and if fixation method of titanium mesh affects the result. We designed an experimental model and created critical size defect (CSD) on calvarium of young rabbit and reconstructed using titanium mesh with two different fixation method. At the end of the calvarial development, we performed the analysis of suture lengths both ispilateral and contralateral of CSD.

\section{MATERIALS AND METHODS}

All the procedures in this study were approved by the Institutional Animal Care and Use Committee and conformed to the Helsinki Declaration. Permission was obtained from Hacettepe University Experimental Animals Ethichal Committee for the study (2010/524). A total of 24 female 6 -week old New Zaeland rabbit were used in the study.

\section{Groups:}

Four groups with 6 rabbits in each group were created. Group 1 was the normal population group for standart suture length mesurements. Group 2 was

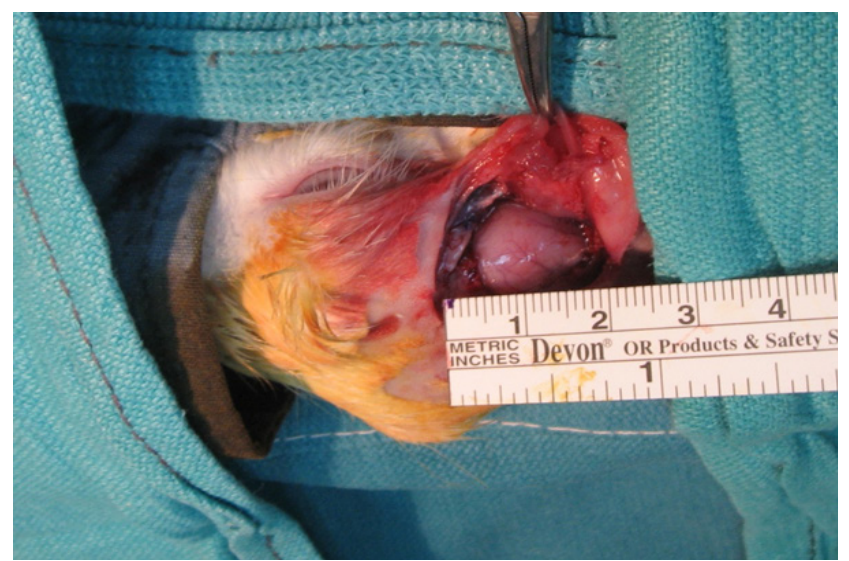

Figure 1. $15 \mathrm{~mm}$. diameter critical size defect on rabbit parietal calvarium.

the sham group; a 15-mm. diameter sized critical size defect created on one side parietal bone. Group 3 was the semirigid fixation group and group 4 was the rigid fixation group.

\section{Surgery:}

All animals underwent surgery on the same day. They received anesthesia with $35 \mathrm{mg} / \mathrm{kg}$ intramuscular ketamine (Ketalar 2\%, Pfizer, İstanbul, Turkey) and $5 \mathrm{mg} / \mathrm{kg}$ xylazine (Rompun, Bayer, İstanbul, Turkey) injections. The incision line was shaved, and the surgical area was cleaned with iodine solution (Batikon, Adeka, Samsun, Turkey). An obliq paramidline skin incision from the parietal to the nasal region was made. The skin and periosteum were reflected laterally, and calvarial sutures were identified. Bicortical calvarial defect was created with using $15 \mathrm{~mm}$. diameter trepan on parietal bone of each rabbit in group 2, 3 and 4 (Figure 1). Defect

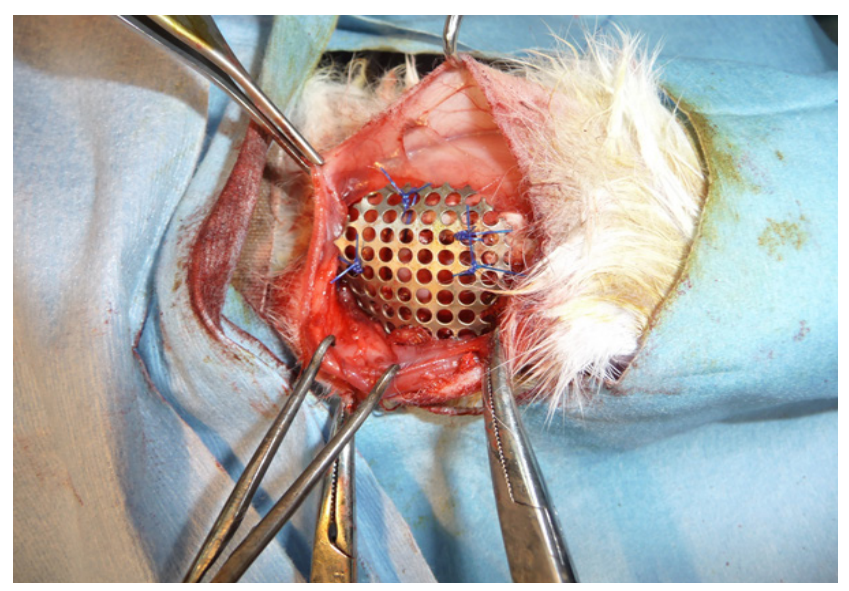

Figure 2. Semirigid fixation of mesh with 3.0 prolene sutur at group 3 . 


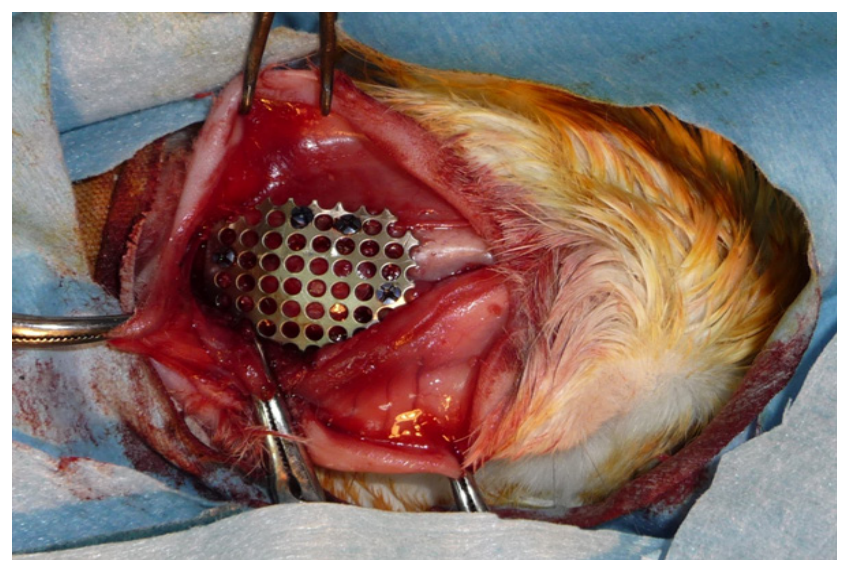

Figure 3. Rigid fixation of mesh with titanium screws at group 4

reconstruction of rabbits in group 3 was performed

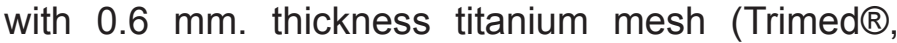
Ankara, Turkey). Mesh was fixed to calvarium with 4.0 Prolene ${ }^{\circledR}$ sutures (Ethicon, Johnson and Johnson Intl., Diegem, Belgium) (Figure 2). Defect reconstruction of rabbits in group 4 was performed with $0.6 \mathrm{~mm}$. thickness titanium mesh (Trimed®, Ankara, Turkey). Mesh was fixed to calvarium with $1.6 \mathrm{~mm}$. diameter, $4 \mathrm{~mm}$. long miniscrews (Trimed®,Ankara, Turkey) (Figure 3). Skin incision was sutured with 4.0 prolene. Cranial Computed Tomography Scan and 3

\section{Dimensional Reconstruction:}

In all groups after anesthesia induction, rabbits were transported to radiology department and 0.75 $\mathrm{mm}$. slice scans were performed at 6 week (Somatom Emotion 6 CT Scanner, Siemens, Erlangen, Germany). All images were transferred to a workstation

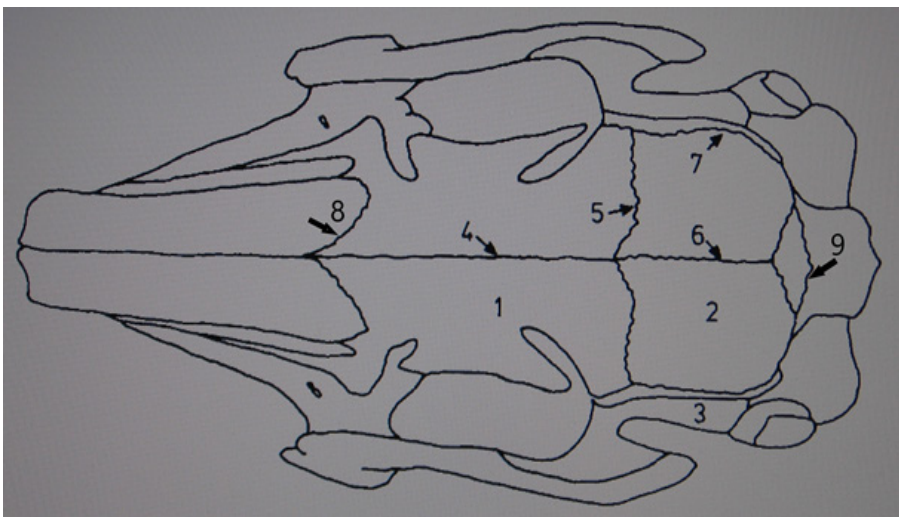

Figure 4. Rabbit calvarium sutures; 1) Frontal bone, 2) Parietal bone, 3) Temporal bone, 4) interfrontal sutur, 5) right coronal sutur, 6) saggital sutur, 7) right temporal sutur, 8) right frontal sutur, 9) occipitointerparietal sutur.
(LEONARDO, Siemens Medical Solutions, Erlangen, Germany). 3D reconstructions were performed by software with soft tissue window slices (Syngofast, Siemens, Erlangen, Germany). After 12 weeks, all rabbits were sacrified with $\mathrm{CO}_{2}$ under high pressure. Titanium mesh implants were removed in groups 3 and 4. All rabbits were transported to radiology department and same procedure was repeated for each in all groups. Length of interfrontal, sagittal, occipitointerparietal and length of frontal, coronal, temporal, occipitoparietal sutures at ipsilateral and contralateral of calvarial defect were measured from 3D CT images (Figure 4-6).

\section{Statistical Analysis:}

Statistical Package for Social Sciences (SPSS) for Windows 15.0 (SPSS Inc.; Armonk, NY, USA) was used for statistical analysis. As a result of the parametric distribution of the values, parametric tests were used. The Shapiro Wilk test was used to investigate whether the distribution of data was close to normal. The homogeneity of the variances was examined by the Levene test. Descriptive statistics were expressed as mean \pm standard deviation. Whether there was a statistically significant difference between the repeated measures in the groups was examined by the t-test. The significance of differences between the groups in terms of averages was evaluated by one way ANOVA.

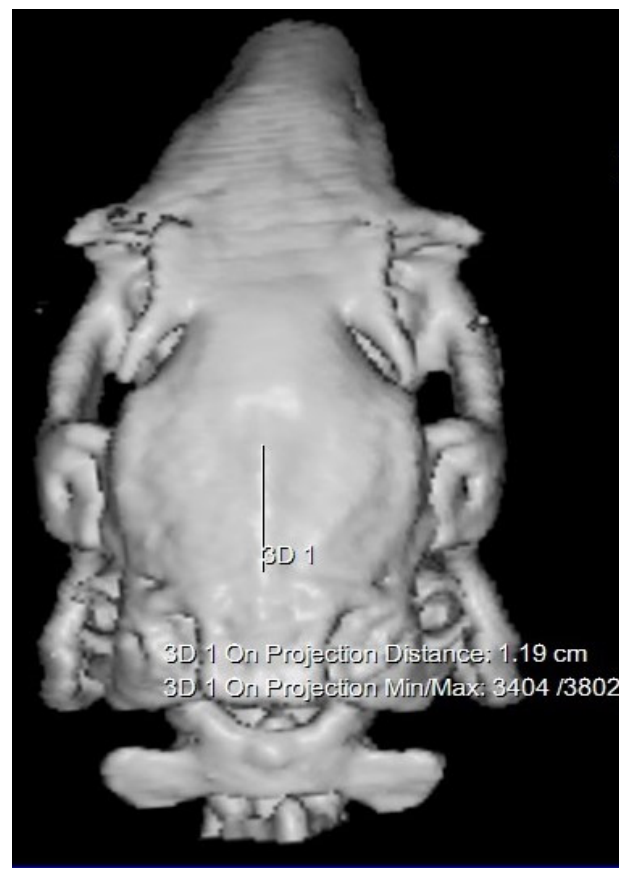

Figure 5. An example of saggital sutur measurement of 6 week-old rabbit with $3 \mathrm{D}$ CT. 


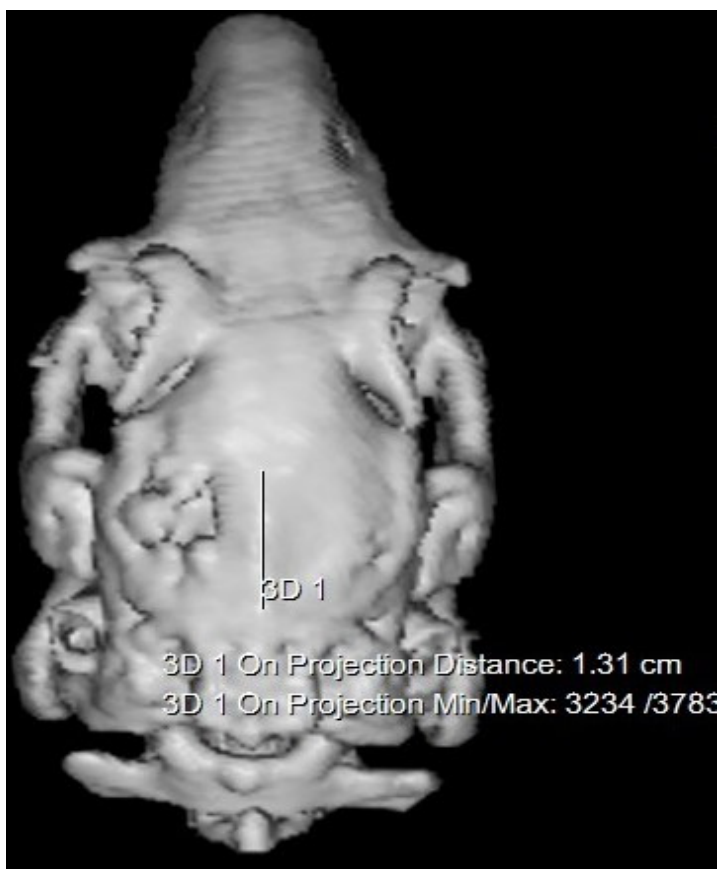

Figure 6. An example of saggital sutur measurement of 18 week-old rabbit with 3D CT. Critical size defect can be seen on left parietal bone.

\section{RESULTS}

All of the rabbits tolerated the procedures and survived untill the end of the study.

\section{D CT Measurements at 6th Week:}

There was no statistically differences between groups and contralateral length of sutures in the same group. As a result, group populations were wellbalanced (Table 1,2).

\section{D CT Measurements at 18th Week:}

Suture lengths were measured in all groups. Defect side and contralateral side measurements were compared within the group as well as between the groups. Standard deviations of length measurements were calculated in groups and the differences were evaluated by one way ANOVA. The relationship between the BT measurements at the 18th week was assessed by the dependent t-test. Corrections were made according to Bonferroni correction. The evaluation of the mutually symmetric length measurements was made as the defect side and the opposite side. As there was no statistical difference between right and left sides in symmetric measurements in group 1, the right side was based on the defect side and the left side was based on the opposite side. According to evaluation, there was no statistical differences for single suture mean values between groups and for contralateral suture mean values in each group and between groups (Table 3,4).

\section{DISCUSSION}

There is no consensus still in the literature about calvarial defect reconstruction of complex and very large skull defects in pediatric patients, although an autologous bone graft is the first choice for many authors (11-13). Resorption and failure of the graft correlates with the size of the calvarial defect strongly. While the defects smaller than $75 \mathrm{~cm}^{2}$ has no failure, defects larger than $75 \mathrm{~cm}^{2}$ have a failure rate greater than $60 \%$ (14). In the pediatric age group, bone graft donor area is limited. Different reconstruction options were needed because of additional morbidity in the donor area, prolongation of operation time, excessive blood loss, more resorption in bone grafts outside the calvarium, and difficulty in splitting the calvarial bones as a result of unformed diploic space before the age of six years.

Allogeneic bone grafts provide an alternative source when the autologous bone source is limited. Infection rate was reported between $0 \%$ and $9.5 \%$ $(15,16)$. In Vargel et al.'s study, long-term bone resorption rate was reported to be between $10 \%$ and $90 \%$ in $29 \%$ of patients enrolled in the study (16).

The complication rate in reconstruction with titanium is lower than in other alloplastic materials. At low complication rates $(<2.5 \%)$ reported with hydroxyapatite cement and Polymethyl methacrylate, the defect area was reported below $6 \mathrm{~cm}^{2}(7)$. Titanium is used as individual design implant and mesh for calvarial defect reconstruction. Use as an implant requires good preoperative evaluation, cranial CT assisted planning and production. Titanium mesh offers an intraoperative styling option and is also used to support other reconstruction materials such

Table 1. Single sutures mean length values of groups at 6 th week.

\begin{tabular}{llllll}
\hline & Group 1 & Group 2 & Group 3 & Group 4 & p-value \\
\hline Interfrontal & $29.49 \pm 1.07$ & $29.12 \pm 1.38$ & $29.13 \pm 0.57$ & $28.97 \pm 0.87$ & 0.841 \\
Sagittal & $14.00 \pm 0.91$ & $14.07 \pm 0.96$ & $14.61 \pm 0.44$ & $13.95 \pm 0.44$ & 0.393 \\
Occipitointerparietal & $9.13 \pm 0.25$ & $9.20 \pm 0.18$ & $9.28 \pm 0.10$ & $8.94 \pm 0.21$ & 0.042 \\
\hline
\end{tabular}

According to the One-Way ANOVA, Bonferroni Correction, the results were considered to be statistically significant for $p<0.017$. 
Table 2. Symmetrical sutures mean length values of groups at 6 th week.

\begin{tabular}{|c|c|c|c|c|c|}
\hline & Group 1 & Group 2 & Group 3 & Group 4 & $p$ - value ${ }^{a}$ \\
\hline Right frontal & $21.94 \pm 1.12$ & $22.16 \pm 0.69$ & $22.19 \pm 0.57$ & $22.55 \pm 0.50$ & 0.589 \\
\hline Left frontal & $21.98 \pm 1.26$ & $22.59 \pm 0.41$ & $22.31 \pm 0.47$ & $22.31 \pm 0.62$ & 0.605 \\
\hline$p$ - value ${ }^{b}$ & 0.841 & 0.049 & 0.195 & 0.019 & - \\
\hline Right coronal & $9.65 \pm 0,63$ & $9.37 \pm 0.67$ & $9.55 \pm 0.44$ & $9.17 \pm 0.37$ & 0.460 \\
\hline Left coronal & $9.67 \pm 0.56$ & $9.51 \pm 0.88$ & $9.60 \pm 0.53$ & $9.07 \pm 0.51$ & 0.388 \\
\hline$p$ - value ${ }^{b}$ & 0.867 & 0.352 & 0.360 & 0.391 & - \\
\hline Right temporal & $13.62 \pm 0.48$ & $13.34 \pm 0.35$ & $13.88 \pm 0.29$ & $13.42 \pm 0.36$ & 0.093 \\
\hline Left temporal & $15.29 \pm 0.59$ & $15.17 \pm 0.74$ & $15.38 \pm 1.90$ & $16.08 \pm 1.03$ & 0.150 \\
\hline$p$ - value ${ }^{b}$ & 0.871 & 0.067 & 0.507 & 0.662 & 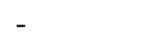 \\
\hline Right lambdoid & $7.77 \pm 0.19$ & $7.91 \pm 0.12$ & $7.96 \pm 0.19$ & $8.00 \pm 0.21$ & 0.169 \\
\hline Left lambdoid & $7.82 \pm 0.18$ & $7.95 \pm 0.21$ & $8.00 \pm 0.15$ & $7.91 \pm 0.16$ & 0.349 \\
\hline$p$ - value ${ }^{b}$ & 0.609 & 0.704 & 0.409 & 0.161 & - \\
\hline
\end{tabular}

a According to the One-Way ANOVA, Bonferroni Correction, the results were considered to be statistically significant for $p<0.008$. $b$ According to the dependent t-test, Bonferroni Correction, the results for $p<0.004$ were considered statistically significant.

as hydroxyapatite. Complication rates have been reported between $0 \%$ and $20 \%$ for implant use $(7$, 17). The implant exposition was $6.7 \%$ due to infection and wound dissociation (17). Complications rates between 0 and $2.3 \%$ were reported for titanium mesh $(6,18)$. The most common complication is infection (18). In long term follow-up, satisfaction rate from aesthetic appearance reaches $97 \%$ (7).

Titanium mesh use was reported in infant and childhood over dura mater or pericranium for large defects in the literature $(8,9,19)$. Fixation method was signified by Vignes et al. and aesthetic outcomes and symmetry were evaluated clinically in all three reports.

The concept of CSD has been described to standardize the search for alternative methods for reconstruction of calvarium defects. It was initially defined as defects in size that would not spontaneously close through the subjects' lives (20). However, the definition has been revised, taking into account that experiments can not be sustained throughout the life of the subjects and is described as defects of a size that can not be closed by itself during the experiment $(20,21)$. Many studies were performed with creating CSD on rabbit calvarium and a defect of $15 \mathrm{~mm}$ in diameter was widely accepted (21-25). Although there was no CSD defined in the developing rabbit calvarium, Mabbut et al.'s study showed that in one-week old subjects, regeneration potential was observed with intermittent plain radiographs after total calvarectomy, and defects were close to total between 3 and 6 week after surgery (26). The study by Selvik et al. reported that the fastest bone growth in rabbits was between 4-6 weeks (27). Masoud et al. revealed that 18 -week-old rabbits reached $91 \%$ of adult rabbit calvarium sizes (28). Since our study targeted critical size defect reconstruction, subjects were selected at the 6th week of rapid bone growth and the experiment was terminated at the 18th week after $91 \%$ of the calvarium development was completed. In addition, the postoperative 12-week time period is in accordance with the time interval in which the defect healing is completed and the longterm outcome is evaluated.

When the results of our study were evaluated, all groups had homogeneous length measurement distribution in the 6-week-old subjects. However, when the interfrontal length means were evaluated, significantly longer mean values were obtained when compared with Burrow et al. and Selvik et al. Also no difference was found between the defect side and the opposite side lengths in both groups and between the groups when the 18th week length measurements were evaluated. Similarly, in parallel to the sixth week measurements, the interfrontal length was longer in all subjects than in the results of Selvik et al.

In this study, 6 week-old subjects were selected. However, the subjects in this age group can not give

Table 3. Single sutures mean length values of groups at 18 th week.

\begin{tabular}{llllll}
\hline & Group 1 & Group 2 & Group 3 & Group 4 & p-value \\
\hline Interfrontal & $34.88 \pm 1.25$ & $34.65 \pm 1.73$ & $35.30 \pm 1.33$ & $34.86 \pm 2.05$ & 0.917 \\
Sagittal & $16.79 \pm 0.89$ & $17.22 \pm 1.82$ & $17.68 \pm 0.73$ & $17.53 \pm 0.37$ & 0.519 \\
Occipitointerparietal & $11.72 \pm 0.59$ & $11.85 \pm 0.41$ & $11.51 \pm 0.89$ & $12.03 \pm 0.48$ & 0.528 \\
\hline
\end{tabular}

According to the One-Way ANOVA, Bonferroni Correction, the results were considered to be statistically significant for $p<0.017$. 
Table 4. Symmetrical sutures mean length values of groups at 18 th week.

\begin{tabular}{|c|c|c|c|c|c|}
\hline & Group 1 & Group 2 & Group 3 & Group 4 & $p$ - value ${ }^{a}$ \\
\hline Frontal defect side & $27.26 \pm 1.32$ & $27.84 \pm 1.01$ & $28.28 \pm 0.54$ & $27.35 \pm 1.06$ & 0.313 \\
\hline Frontal contralateral side & $27.13 \pm 1.48$ & $28.30 \pm 0.78$ & $27.72 \pm 0.39$ & $27.16 \pm 0.98$ & 0.165 \\
\hline$p$ - value ${ }^{b}$ & 0.841 & 0.049 & 0.195 & 0.019 & \\
\hline Coronal defect side & $12.40 \pm 0.41$ & $12.73 \pm 0.70$ & $13.28 \pm 0.85$ & $12.71 \pm 0.60$ & 0.167 \\
\hline Coronal contralateral side & $12.12 \pm 0.50$ & $12.52 \pm 0.97$ & $12.96 \pm 0.44$ & $12.48 \pm 0.49$ & 0.193 \\
\hline$p-$ value $^{b}$ & 0.077 & 0.324 & 0.259 & 0.269 & - \\
\hline Temporal defect side & $15.83 \pm 0.54$ & $15.34 \pm 0.69$ & $15.41 \pm 2.00$ & $16.01 \pm 1.08$ & 0.554 \\
\hline Temporal contralateral side & $13.60 \pm 0.41$ & $13.58 \pm 0.52$ & $13.94 \pm 0.43$ & $13.33 \pm 0.37$ & 0.894 \\
\hline$p-$ value $^{b}$ & 0.330 & 0.706 & 0.935 & 0.018 & - \\
\hline Lambdoid defect side & $8.53 \pm 0.21$ & $9.91 \pm 0.33$ & $10.33 \pm 1.85$ & $9.87 \pm 0.68$ & 0.029 \\
\hline Lambdoid contralateral side & $8.68 \pm 0.58$ & $9.62 \pm 0.50$ & $9.22 \pm 0.89$ & $9.77 \pm 0.49$ & 0.035 \\
\hline$p$ - valueB & 0.544 & 0.028 & 0.240 & 0.534 & - \\
\hline
\end{tabular}

a According to the One-Way ANOVA, Bonferroni Correction, the results were considered to be statistically significant for $p<0.008$. $b$ According to the dependent $t$-test, Bonferroni Correction, the results for $p<0.004$ were considered statistically significant.

any idea about the population with the calvarium defect in the human infant age group. Rapid calvarium development in rabbits and the potential for bone regeneration to be greater than in humans is another weak point of this experimental model (29).

In conclusion, titanium mesh allows intraoperative shaping. It does not require pre-preparation like 3D implanted implants. It can become a suitable reconstruction option in the pediatric age group with growing calvarium because it is much less costly than reconstruction with a titanium implant, but also has advantages of reconstruction with titanium and significantly less complication rate than other reconstruction options.

Conflict of interest: Authors declare that there is no conflict of interest between the authors of the article.

Financial conflict of interest: This study was supported by Hacettepe University Coordination Department of Scientific Research Projects with the project number of $010 D 09101008$ in 2011.

Address correspondence to: Mustafa Kursat Evrenos, Celal Bayar University, Faculty of Medicine, Department of Plastic Reconstructive and Aesthetic Surgery, Manisa

e-mail: mkevrenos@hotmail.com

\section{REFERENCES}

1. Hockley AD, Goldin JH, Wake MJ, et al. Skull repair in children. Pediatr Neurosurg 1990;16(4-5):271-5.

2. Losee JE, Karmacharya J, Gannon FH, et al. Reconstruction of the immature craniofacial skeleton with a carbonated calcium phosphate bone cement: Interaction with bioresorbable mesh. J Craniofac Surg 2003;14(1):117-24.

3. Lykins CL, Friedman CD, Costantino PD, et al. Hydroxyapatite cement in craniofacial skeletal reconstruction and its effects on the developing craniofacial skeleton. Arch Otolaryngol Head Neck Surg 1998;124(2):153-9.

4. Blake GB, Mac Farlane MR, Hinton JW. Titanium in reconstructive surgery of the skull and face. Br J Plast Surg 1990;43(5):528-35.

5. Williams LR, Fan KF, Bentley RP. Custom-made titanium cranioplasty: Early and late complications of 151 cranioplasties and review of the literature. Int J Oral Maxillofac Surg 2015;44(5):599-608.

6. Kuttenberger JJ, Hardt N. Long-term results following reconstruction of craniofacial defects with titanium micromesh systems. J Maxillofac Surg 2001;29(2):75-81.

7. Cabraja M, Klein M, Lehmann TN. Long-term results following titanium cranioplasty of large skull defects. Neurosurg Focus 2009;26(6):E10.

8. Vignes JR, Jeelani NO, Dautheribes M, et al. Cranioplasty for repair of a large bone defect in a growing skull fracture in children. J Craniomaxillofac Surg 2007;35(3):185-8.

9. Ma IT, Symon MR, Bristol RE, et al. Outcomes of titanium mesh cranioplasty in pediatric patients. J Craniofac Surg 2018;29(1):99-104.

10. Williams L, Fan K, Bentley R. Titanium cranioplasty in children and adolescents. J Craniomaxillofac Surg 2016;44(7):78994.

11. Flannery T, McConnell RS. Cranioplasty: Why throw the bone flap out? Br J Neurosurg 2001;15(6):518-20.

12. Hayward RD. Cranioplasty: Don't forget the patient's own bone is cheaper than titanium. Br J Neurosurg 1999;13(5):490-1.

13. Iwama $\mathrm{T}$, Yamada $\mathrm{J}$, Imai $\mathrm{S}$, et al. The use of frozen autogenous bone flaps in delayed cranioplasty revisited. Neurosurgery 2003;52(3):591-6; discussion 5-6.

14. Goiato MC, Anchieta RB, Pita MS, et al. Reconstruction of skull defects: Currently available materials. J Craniofac Surg 2009;20(5):1512-8.

15. Chen TM, Wang HJ. Cranioplasty using allogeneic perforated demineralized bone matrix with autogenous bone paste. Ann Plast Surg 2002;49(3):272-7.

16. Vargel I, Tuncbilek G, Mavili E, et al. Solvent-dehydrated calvarial allografts in craniofacial surgery. Plast Reconstr Surg 2004;114(2):298-306.

17. Heissler E, Fischer FS, Bolouri S, et al. Custom-made cast titanium implants produced with CAD/CAM for the reconstruction of cranium defects. Int J Oral Maxillofac Surg 1998;27(5):334-8.

18. Gear AJ, Lokeh A, Aldridge JH, et al. Safety of titanium mesh for orbital reconstruction. Ann Plast Surg 2002;48(1):1-7; 
discussion -9 .

19. Josan VA, Sgouros S, Walsh AR, et al. Cranioplasty in children. Childs Nerv Syst 2005;21(3):200-4.

20. Schmitz JP, Hollinger JO. The critical size defect as an experimental model for craniomandibulofacial nonunions. Clin Orthop Relat Res 1986(205):299-308.

21. Sohn JY, Park JC, Um YJ, et al. Spontaneous healing capacity of rabbit cranial defects of various sizes. J Periodontal Implant Sci 2010;40(4):180-7.

22. Haddad AJ, Peel SA, Clokie CM, et al. Closure of rabbit calvarial critical-sized defects using protective composite allogeneic and alloplastic bone substitutes. J Craniofac Surg 2006;17(5):926-34.

23. Urist MR. New advances in bone resarch. West J Med 1984;141-52.

24. Ma D, Ren L, Chen F, et al. Reconstruction of rabbit criticalsize calvarial defects using autologous bone marrow stromal cell sheets. Ann Plast Surg 2010;65(2):259-65.
25. Shand JM, Heggie AA, Holmes AD, et al. Allogeneic bone grafting of calvarial defects: An experimental study in the rabbit. Int J Oral Maxillofac Surg 2002;31(5):525-31.

26. Mabbutt LW, Kokich VG. Calvarial and sutural redevelopment following craniectomy in the neonatal rabbit. $J$ Anat 1979;129(Pt 2):413-22.

27. Alberius $P$, Selvik $G$. Kinematics of cranial vault growth in rabbits. Am J Anat 1983;168(3):321-30.

28. Masoud I, Shapiro F, Moses A. Longitudinal roentgencephalometric study of the growth of the New Zealand white rabbit: Cumulative and biweekly incremental growth rates for skull and mandible. J Craniofac Genet Dev Biol 1986;6(3):259-87.

29. Persson M, Magnusson BC, Thilander B. Sutural closure in rabbit and man: A morphological and histochemical study. $J$ Anat 1978;125(2):313-21. 